\title{
Belphégor
}

\section{Robert Lance Snyder (Ed.), Espionage Fiction: The Seduction of Clandestinity}

\section{Karen Ferreira-Meyers}

\section{(2) OpenEdition}

1 Journals

\section{Electronic version}

URL: http://journals.openedition.org/belphegor/508

DOI: 10.4000/belphegor.508

ISSN: 1499-7185

Publisher

LPCM

\section{Electronic reference}

Karen Ferreira-Meyers, «Robert Lance Snyder (Ed.), Espionage Fiction : The Seduction of Clandestinity », Belphégor [Online], 12-1 | 2014, Online since 12 June 2014, connection on 22 September 2020. URL http://journals.openedition.org/belphegor/508 ; DOI : https://doi.org/10.4000/belphegor.508

This text was automatically generated on 22 September 2020 .

\section{(c) (i) (9)}

Belphégor est mis à disposition selon les termes de la Licence Creative Commons Attribution - Pas d'Utilisation Commerciale - Pas de Modification 4.0 International. 


\title{
Robert Lance Snyder (Ed.), Espionage Fiction: The Seduction of Clandestinity
}

\author{
Karen Ferreira-Meyers
}

\section{REFERENCES}

SNYDER, Robert Lance (Ed.), Espionage Fiction : The Seduction of Clandestinity, Paradoxa 24, Vashon Island: Paradoxa, 2012, 289 p., ISBN 1-929512-35-X, 978-1-929512-35-5, ISSN 1079-8072 
1 Paradoxa publishes Studies in World Literary Genres. This particular volume, Paradoxa 24, is entitled Espionage Fiction: The Seduction of Clandestinity. A total of 11 essays, 3 interviews and 3 book reviews are included in the publication.

2 In his introductory essay, Robert Lance Snyder (who is also the editor of the volume) explains the objectives of this collection. The first objective is to challenge espionage fiction's historical pattern of androcentrism, the second one is to expand coverage beyond its usual Anglo-American parameters, the third and last one is to devote at least equal attention to post-Cold War spy narratives as to those published before 1991. The publication of the volume was preceded by a Call for Papers, launched in the summer of 2011, barely a year before its

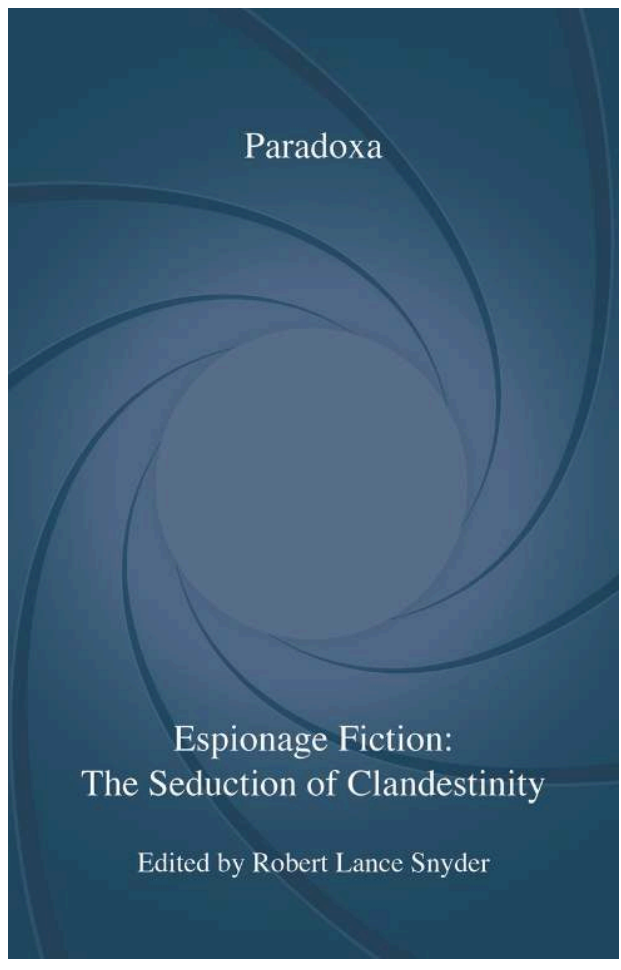
going to the press.

3 Looking at the position of women in espionage fiction, the essays by Emma Grundy Haigh, Christine Bold, Mary Anne Schofield, Charlotte Beyer and Rosie White all aspire to jettison female stereotypes traditionally used in this type of crime fiction. Indeed, in "In Light of the Other, the Hero and the Adversarial Spy", Grundy Haigh paves the way for feminist reconsideration of "Otherness" dynamics. She concludes that the spy-hero must recognize his own Otherness and interrogate his subjectivity. Christine Bold aptly analyses Helen MacInnes' spy fiction and her introduction of marriage as a literary innovation in this genre. Bold sees MacInnes' women characters as a significant stage in the process of emergence of women's voices in espionage narratives. Examples of espionage novels resisting closure and revelling in ambiguity are found in Manning Coles' oeuvre, according to Mary Anne Schofield. The authors, Adelaide Frances Oke Manning and Cyril Henri Coles, the duo that makes up Manning Coles, offer intriguing ways of viewing the wartime order of identity, fictionally and politically, at the moment of their publication. Schofield seems to allude to the fact that the writing was different from other contemporary spy fiction because one of the authors was a woman. However, she never goes so far as to explicitly state this. Rosie White, feeling that espionage fiction cannot be analysed without the inevitable reference to the iconic James Bond, centres her essay around notions of age and femininity when demonstrating that Dorothy Gilman's Mrs Pollifax is a great challenge to the misogynistic Bond. The last instalment on women's inclusion and importance in espionage fiction is Charlotte Beyer's essay entitled “Spying Women: Gayle Lynd's Espionage Fiction".

4 The above-mentioned essays all take care of the first objective the editor had set for this volume. The second objective finds a response through three essays, namely Paul Bleton's, mainly bibliographic, study on trends in contemporary Francophone Spy Fiction, Sándor Kálai's paper on Hungarian novelist Vilmos Kondor's The Budapest Spy 
and Bérengère Vachonfranche-Levet's essay on French-Algerian author Hédi Kaddour's highly acclaimed Waltenberg. These essays broaden the playing field of espionage fiction by including European, African and Asian narratives written in French. Sándor Kálai's study gives an overview of Hungarian spy fiction and Vilmos Kondor's crime fiction series, before examining The Budapest Spy, which, although published in a crime fiction series, has numerous characteristics of an espionage narrative. Kálai uses Paul Bleton's theoretical model which suggests that the structure of spy fiction revolves around the State, the Prince, the Organization and the Spy, and are combined with three Machiavellian elements of espionage, namely secrets, deception and violence. Vachonfranche-Levet sees in Waltenberg a roman-monde because it "gives us a brilliant twentieth-century fresco of symmetrical twins and halves that invokes the psychosis of Cold War espionage after the interwar period" (p. 197).

The last section of the essay ensemble, which sought to identify and describe spy fiction in the post-Cold War era, published after 1991, assembles Brian E. Crim's study entitled "(Im)perfect Spies: Identity and the Pathology of the Cold War in John Le Carré's The Perfect Spy and The Secret Pilgrim" and Lee Horsley's analysis of post 9/11 espionage stories which include the dilemmas, alliances and enmities of modern-day life.

In addition to these academic essays, there are three interviews with novelists Gayle Lynds and Olen Steinhauer as well as with LeRoy Lad Panek, one of the first literary critics to look into the British spy novel as a separate field of research.

7 This volume of essays has an added raison d'être, namely to attempt to convince its readers that crime fiction in general and spy fiction in particular can be seen as "good literature" and don't have to be hidden in a far-away corner. It does so in a convincing way, especially since the volume is beautifully edited, has very few grammatical or spelling errors and has a wealth of bibliographical information for any new or seasoned researcher in the area of this particular genre.

\section{AUTHORS}

\section{KAREN FERREIRA-MEYERS}

University of Swaziland 